DOI https://doi.org/10.18551/rjoas.2018-06.54

\title{
ABBREVIATION OF SCALES ON APPLE PLANT IN JUNGGO (TULUNGREJO VILLAGE OF BATU CITY, INDONESIA)
}

\author{
Tito Sama' Iradat ${ }^{\star}$ \\ Postgraduate Program, Faculty of Agriculture, University of Brawijaya, Indonesia \\ Mudjiono Gatot, Abadi Abdul Latief, Himawan Toto \\ Department of Pest and Plant Diseases, Faculty of Agriculture, University of Brawijaya, \\ Indonesia \\ *E-mail: tito bio 04@yahoo.co.id
}

\begin{abstract}
Scales have attacked 9 hectares of apple land spread in 8 villages of Bumiaji sub-district such as Giripurno village, Tulungrejo village, Pandanrejo village, Sumbergondo village, Bulukerto village, Punten village, Gunungsari village, and Bumiaji village. This pest is a perennial pest on apple crops and difficult to control. The current way of control has not been able to overcome this pest problem. This research was conducted to find out abbreviation of scales on apple plant at Junggo, Tulungrejo Village, Bumiaji Sub-district, Batu City. Number of duct tape observed as many as 18 units of experiment and trap color as much as 30 unit experiment. The results showed that the total population of scales that can occur in one year is 1322 individu with a generation of 7.20 months and the rate of breeding speeds of 3.21 in one parent. Decrease of scales occurs in March to May and September to November. In March to May it is suspected to be caused more by natural enemies, whereas in September to November it is caused more by rainfall factor.
\end{abstract}

\section{KEY WORDS}

Abbreviation, apple, scales, pests, control.

Apple plants are horticultural commodities that quite important, because it has a high economic value. Apple production in East Java is Batu City and Poncokusumo district Malang Regency. Increased production of apple crops has made the city of Batu as a center of East Java apple crop. Agro-climate conditions that are generally dry highland is very suitable for apple farming business. Apple plants have tolerance to the height of the place make the identity of Batu City (Sunarjono, 2013).

Batu Town is an apple producing center in Indonesia which has an apple land area of 2,993.89 Ha which is centered in Bumiaji District. Tulungrejo village in Bumiaji district is at an altitude of 700-800 meters above sea level (mdpl) (Fahriyah et al. 2011). Apples area in Tulungrejo village is $400 \mathrm{Ha}$ with total production of apple 11.000 ton per harvest season with productivity 27.5 ton / Ha / year (Indahwati et al, 2012).

Based on information that has been circulating that the scales have attacked 9 hectares of apple land spread in 8 villages Bumiaji District such as Giripurno village, Tulungrejo village, Pandanrejo village, Sumbergondo village, Bulukerto village, Punten village, Gunungsari village and Bumiaji village (Scale attack 9 hectares of apple orchard, Radar Batu Jawa Pos, Saturday 20 August 2015 p. 37-38).

Apples are an annual fruit plant originating from the West Asian region with a subtropical climate. Apples were first introduced by Europeans during the colonial era, and today can be said to have naturalized to be a tropical apple plant. Not much research to discuss about apples in the tropics, especially the scales as pests of these plants (Triwiratno, 2008). Considering that the controlling of scale done by farmers has not been successful, it is necessary to study the pests of scales in tropical area of apple plant by taking the research location at Pedukuan Junggo, Tulungrejo Village, Bumiaji Sub-District, Batu Town from abundance. 


\section{METHODS OF RESEARCH}

Duct tape trap. The duct tape aims to get an active crawler on the surface of an apple plant. The number of samples observed as many as 18 plants and will produce 18 units of experiments.

The duct tape is made by using duct tape with double tip on the plant part which has been estimated to be attacked by pests of scales and adjusted to variation of research height that is $1 \mathrm{~m}$ and $1.5 \mathrm{~m}$. The data obtained is tabulated and calculated the average of the population in apple crops with the formula:

$$
\mu=\frac{\sum x i}{n}
$$

Where:

$\mu$ is the average population per type of insect;

$x i$ is the number of insects found per type of insect;

$\mathrm{n}$ is the number of replications.

At each observation in the field will be installed 18 traps of duct tape and trap taking will be done 3 days after installation. The trapping duct tape interval will be held every 2 weeks. It aims to give time for the identification as well as naturalization of the field (return of the environment under normal conditions). The identification of insects is by using the following guidebook: (1) Identification of scales using Arthropods of economic importance: Diaspididae of the world (Watson, 2002) and (2) Identification of natural enemies using A Pictorial Guide to the species of Encarsia (Hymenoptera: Aphelinidae) parasitic on whiteflies (Homoptera: Aleyrodidae) in North America (Schauff, 2014). Observed with a light microscope on a red ribbon (40x magnification) and with a yellow ribbon (100x magnification).

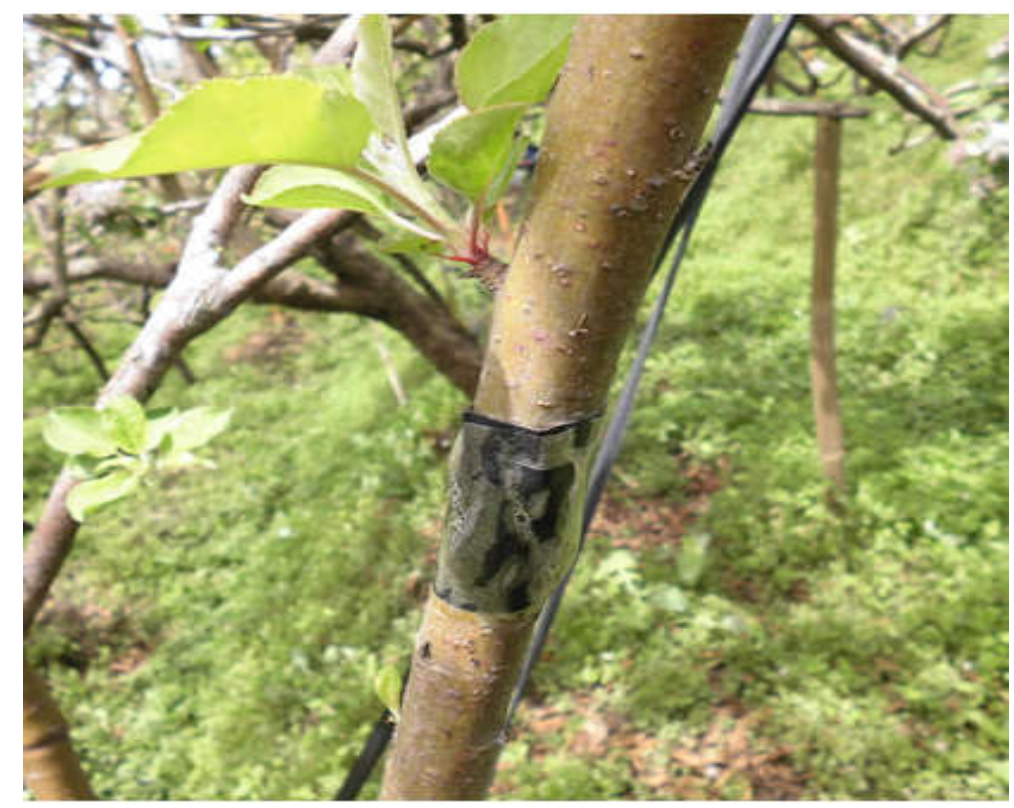

Figure 1 - Duct tape trap

Visual traps / color traps. Visual traps aim to get insects attracted by color and produce 30 experimental units. The visual trap is a colored board measuring $10 \mathrm{~cm} \times 10 \mathrm{~cm}$ with a square shape that has been coated with double-sided tape and hung with wire on the branch of the plant that has been estimated to be attacked by pests of scales and adjusted to variations of research height that is $1 \mathrm{~m}$ and $1.5 \mathrm{~m}$. The data obtained is tabulated and calculated the average of the population in apple crops with the formula (1). 
At each observation in the field will be installed 30 visual traps and trap taking will be done 3 days after installation. The visual trap mounting interval will be held every 2 weeks. It aims to give time for the identification as well as naturalization of the field (return of the environment under normal conditions). The identification of insects is by using the following guidebook: (1) Identification of scales using Arthropods of economic importance: Diaspididae of the world (Watson, 2002) and (2) Identification of natural enemies using A Pictorial Guide to the species of Encarsia (Hymenoptera: Aphelinidae) parasitic on whiteflies (Homoptera: Aleyrodidae) in North America (Schauff, 2014). Observed with a light microscope on a red ribbon (40x magnification) and with a yellow ribbon (100x magnification).

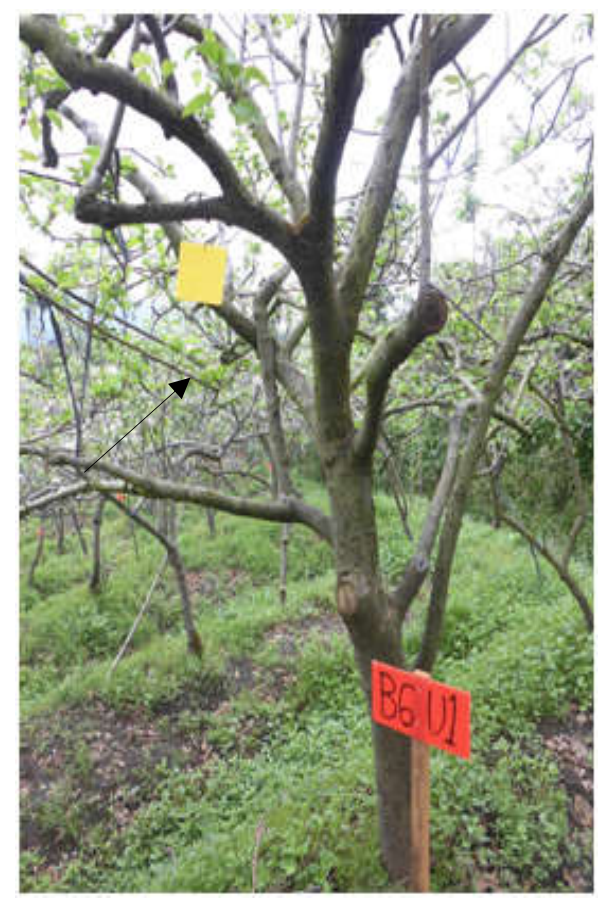

Figure 2 - Visual trap

Data from these two traps are combined to find the total abundance of the scales in the Junggo, Tulungrejo Village, Bumiaji District, Batu City.

\section{RESULTS AND DISCUSSION}

Species of scales on apple plant in Junggo, Tulungrejo Village, Bumiaji District, Batu City. Species of scales found in apple plants in Junggo, Tulungrejo Village, District Bumiaji, Batu City is Diaspidioutus perniciosus (Comstock). Diaspidiotus perniciosus is characterized by the adult female body is transparent, pear-shaped, has no perivulvar pore and the addition of a pair of dorsal setae in the second segment and also ovovivipar.

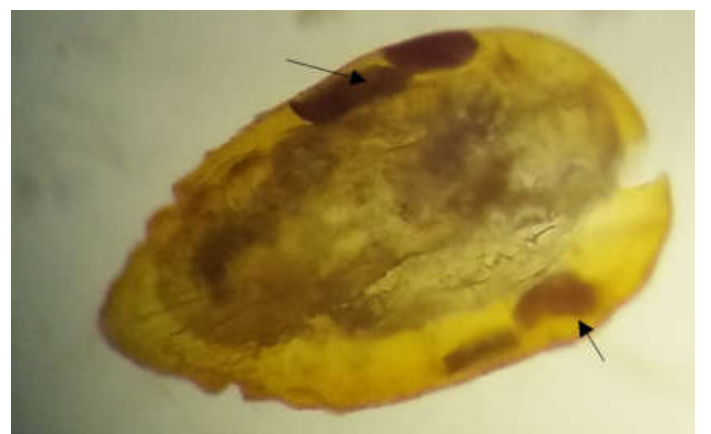

Figure 3 - Setae dorsal (arrow) and ovovivipar of D. perniciosus (Magnification 1:100) 
Adult female morphology and adult males on the scales are different. Adult females lack wings and limbs as in males (Figure 4). The division of adult female bodies is unclear whereas adult males have developed well where there are wings, antennae, legs and can move freely.

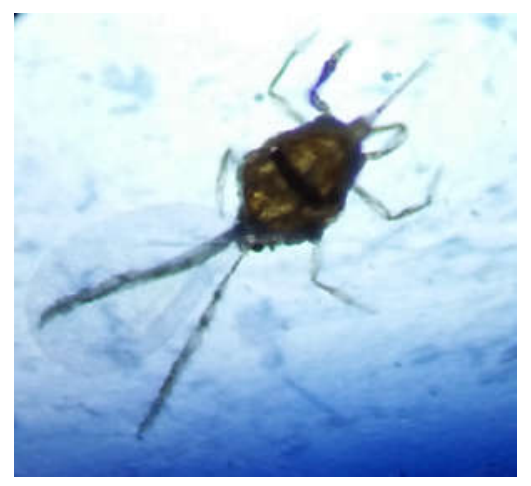

Figure 4 - Adult males D. Perniciosus (Magnification 1:100)

Adult male $D$. perniciosus is a small winged insect with a size of $1 \mathrm{~mm}$ and colored golden brown. This flying males are looking for adult females and mate. The crawler produced by the females is bright yellow and measuring between 0.1-0.24 mm (Figure 5). Once out of the female imago, the crawler will walk or drift because of the wind to a new spot that is infesting babbling, fruit, leaves and also entering the shield. And from the observation, the crawler has been able to create a shield in 1 day. This is contrary to Miller (2005) which states that D. perniciosus can make a shield within 3 days. Differences are sub tropical and tropical.

Figure 5 - Crawler D. Perniciosus (magnification 1:100)

After going through several stages of development that begins by the crawler, it can be seen the difference between males and females. The shield of the male scales is elongated and the female scales shield is a circle and both of two called nymph (Figure 6).
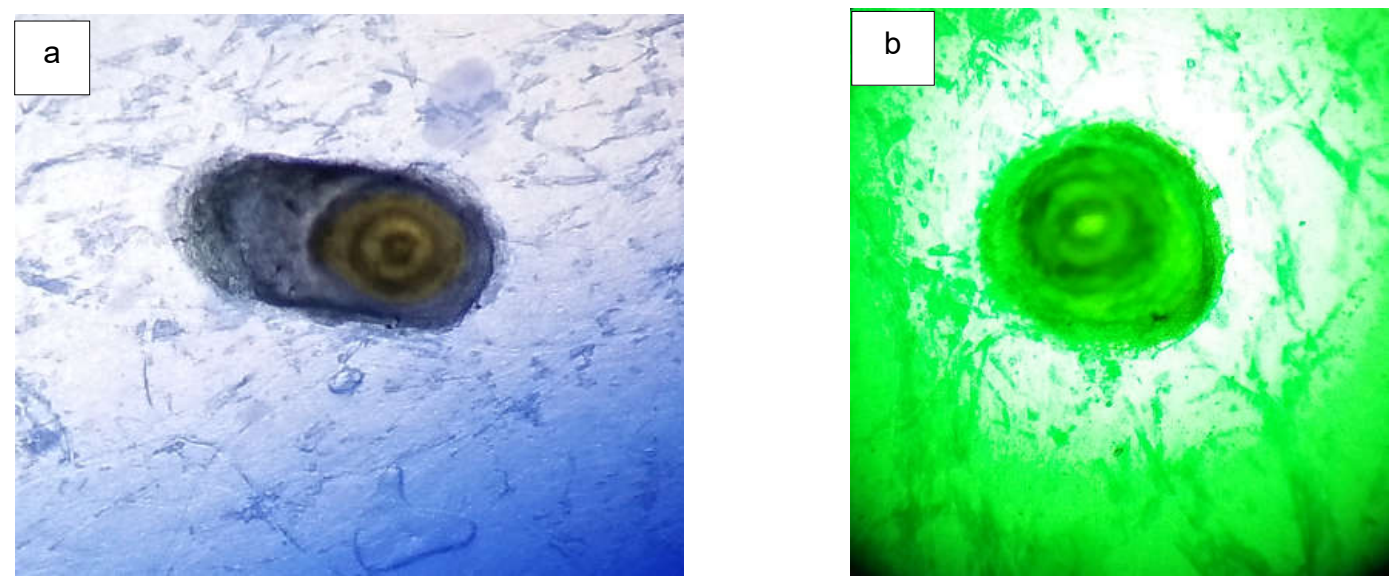

Figure 6 - (a) Male Nymph (b) Female Nymph (Magnification 1:100) 
Based on data, it was found that adult female and crawler decreases were in 2 months to 4 months after defoliation (Figure 7). So it can be concluded the decline occurred in March to May and September to November. In March to May it is suspected to be more caused by natural enemies, whereas in September to November it is caused more by rainfall factor (Figure 8).

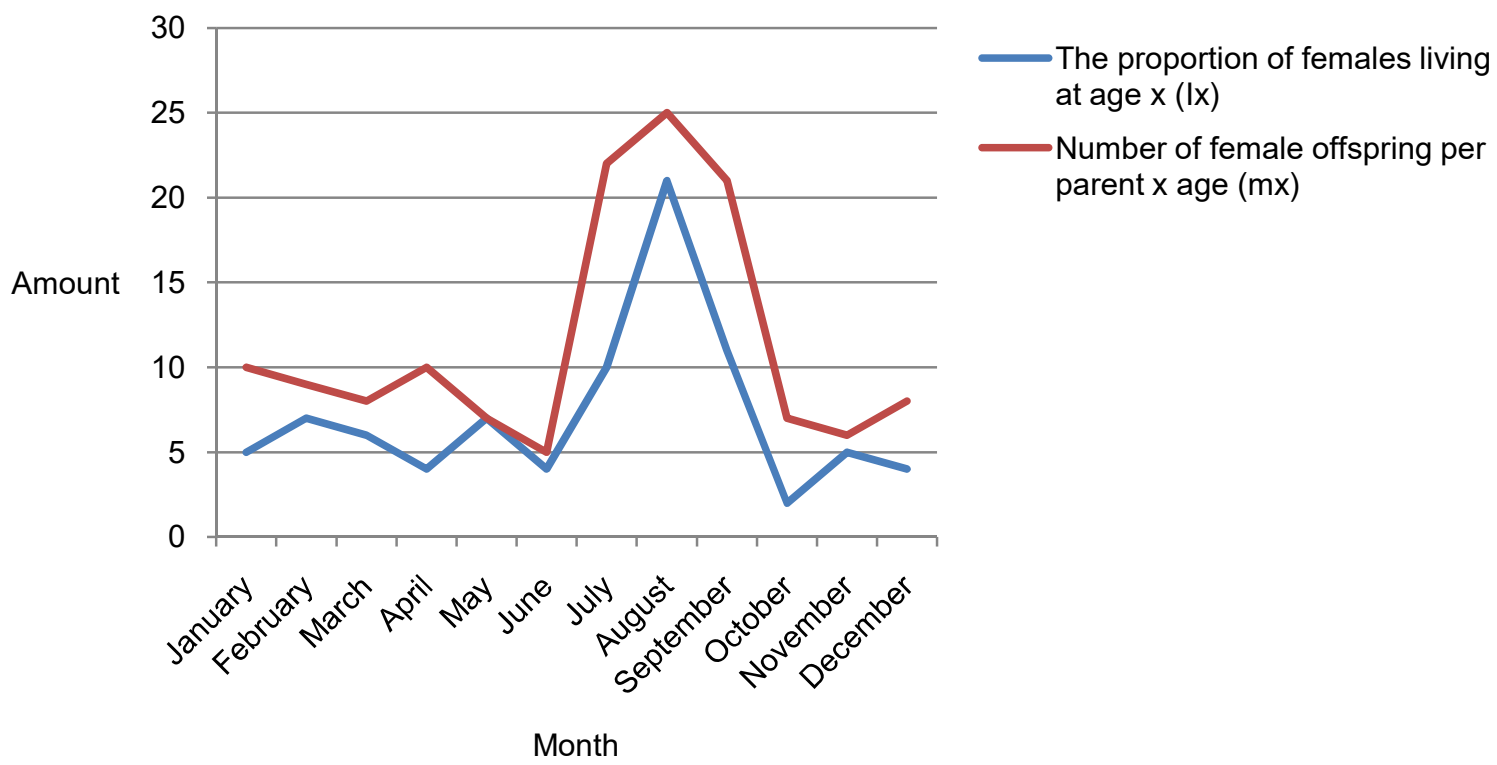

Figure 7 - The number of adult female offspring (crawler) and the proportion of adult females begin to defoliation to harvest

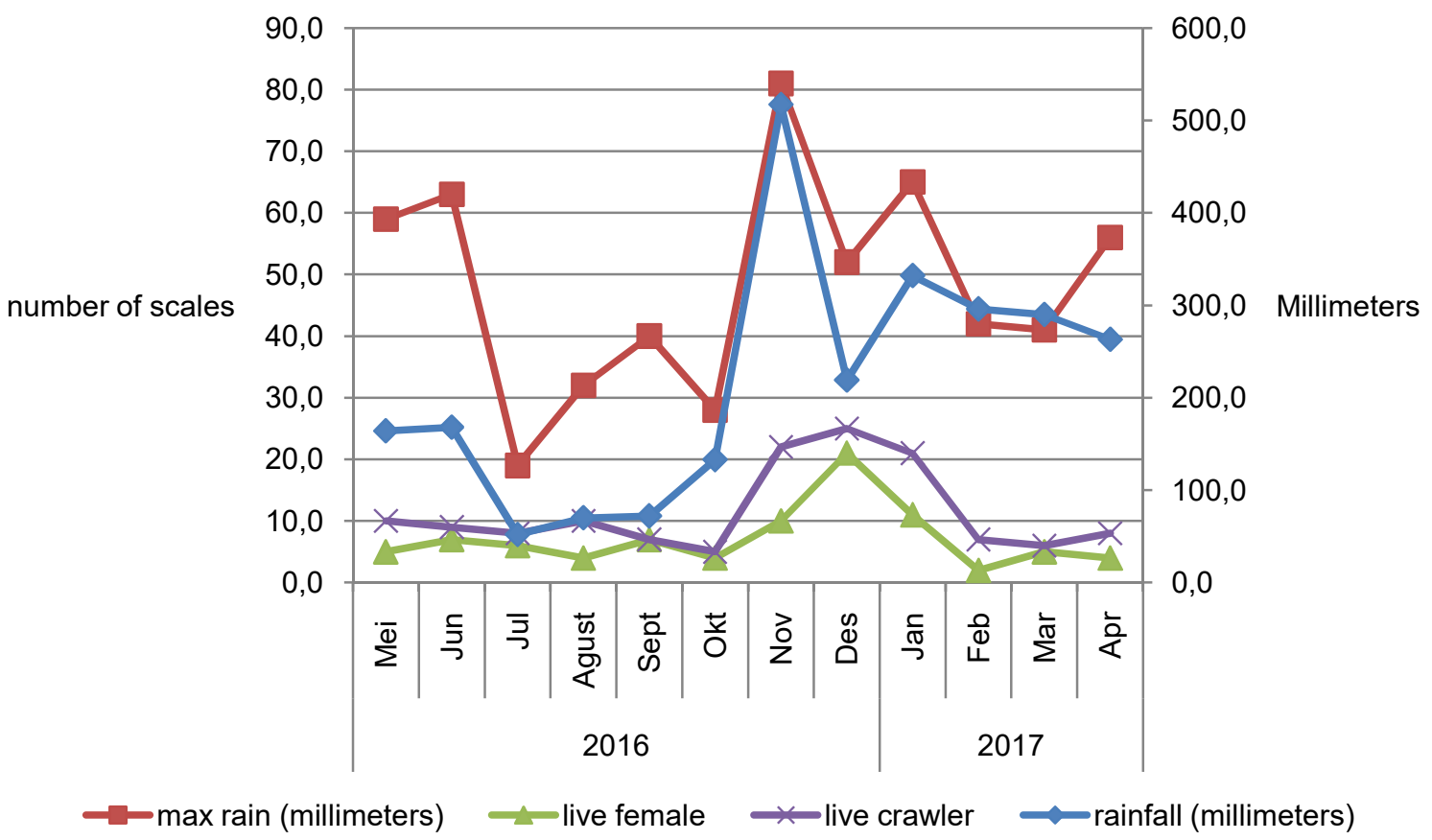

Figure 8 - Rainfall of apple plants and the scale insect

The result of significance test in Figure 9. states that abiotic factor has correlation to the number of scales in the apple plantation area of Tulungrejo village, Bumiaji sub-district, Batu city. The relationship had a significance value of $R 2=0.0042$ at the time of the 12 month study. R2 is the value of determination which means that the sampling time factor has 
a contribution of $0.4 \%$ to the highest number of individuals and $99.6 \%$ is contributed by other factors so it is very difficult for if by considering only abiotic factors.

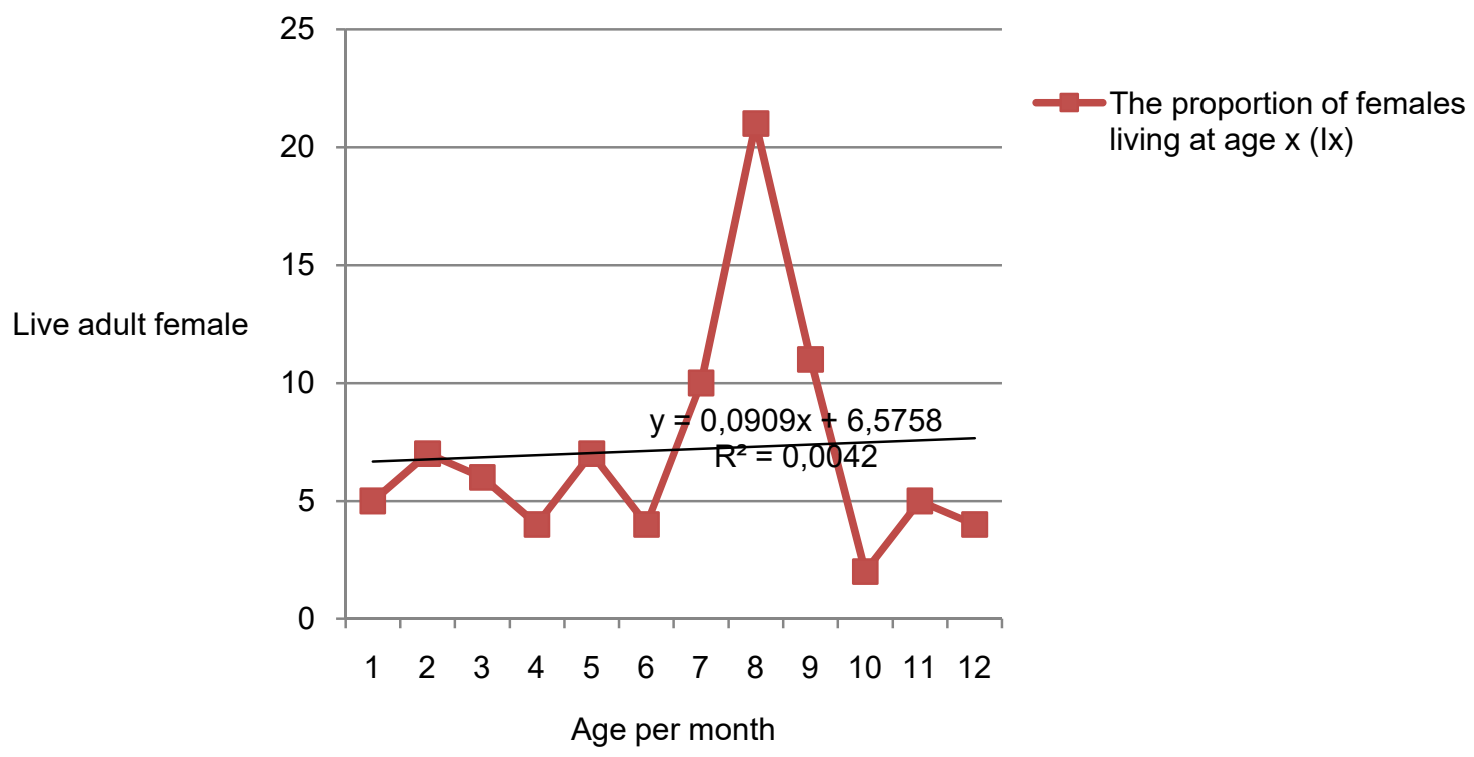

Figure 9 - Females live at a certain age

According to Koteja, (1990), the advantages possessed by scales is from the beginning of the beginning of the formation of the gray border of the females want to accept the males. In this stadium, if not married, the female remains a virgin and does not turn into an adult female during the absence of marriage.

The third instar of the unelected females releases pheromones to attract the male. Pheromone expenditure begins with the formation of a gray layer and can last up to 84 days for no marriage. When married, the pygidium is extended to the edge of the gray layer. After marriage, the pygidium is pulled through the ventral lobe and no more marriage can occur. The stadium is called the adult female (Koteja, 1990).

Table 1 - Clean Reproduction Rate, Old Generation, and Increased Intrinsic Rate

\begin{tabular}{|c|c|c|c|}
\hline Age per month (x) & $\begin{array}{c}\text { The proportion of females } \\
\text { living at age } x(\mathrm{~lx})\end{array}$ & $\begin{array}{c}\text { Number of female offspring } \\
\text { per parent x age }(\mathrm{mx})\end{array}$ & $q x=(|x-| x+1) / \mid x$ \\
\hline 1 & \begin{tabular}{|c|}
5 \\
\end{tabular} & \begin{tabular}{|c|}
10 \\
\end{tabular} & 0,200 \\
\hline 2 & 7 & 9 & 0,143 \\
\hline 3 & 6 & 8 & 0,167 \\
\hline 4 & 4 & 10 & 0,250 \\
\hline 5 & 7 & 7 & 0,143 \\
\hline 6 & 4 & 5 & 0,250 \\
\hline 7 & 10 & 22 & 0,100 \\
\hline 8 & 21 & 25 & 0,048 \\
\hline 9 & 11 & 21 & 0,091 \\
\hline 10 & 2 & 7 & 0,500 \\
\hline 11 & 5 & 6 & 0,200 \\
\hline 12 & 4 & 8 & 0,250 \\
\hline Total & 86 & 138 & 0,012 \\
\hline
\end{tabular}

Net Production rate (RO):

$$
R_{0}=\sum_{n=0}^{n} I_{n} m_{k}=1322 \text { (average population) }
$$


Average generation time $(T)$ :

$$
T=\left(\sum_{i=0}^{n} x I_{i}\left[I I_{n}\right) / R_{0}=7,20\right. \text { month }
$$

Value intrinsic rate $(r)$ :

$$
N_{T}=N_{0} \cdot \exp (r \cdot T)=3,21
$$

Total scales of adult female were found to amount to 86 head and the number of offspring in one year amounted to 138 heads with an intrinsic increase rate of generation of 0.012. The highest speed is in October. But this month, the scales are controlled by high rainfall. The total population of scales that can occur in one year is 1322 individu with a generation of 7.20 months and the rate of breeding speed of 3.21 individu in one sibling.

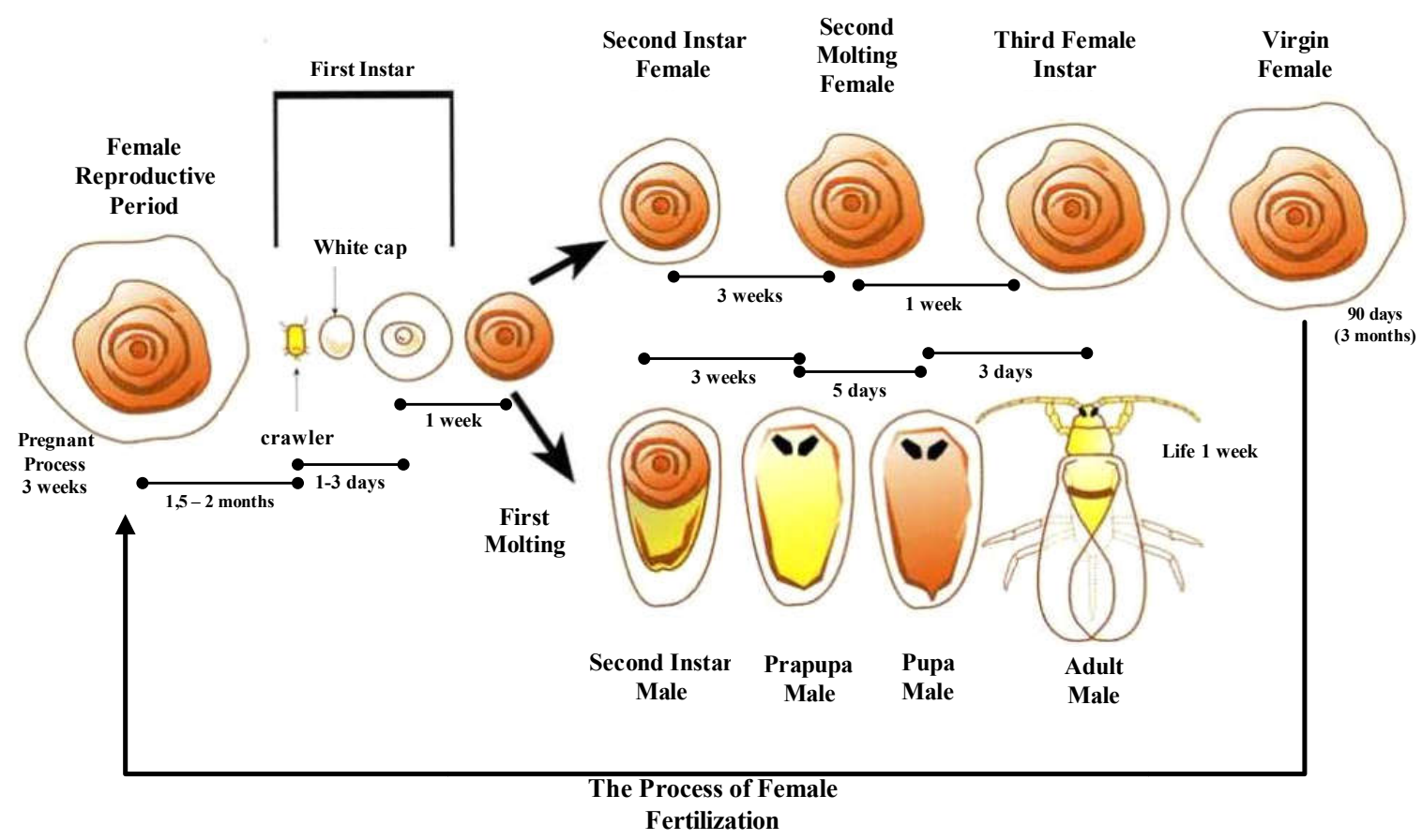

Figure 10 - Life cycle D. Perniciosus (Modification of Rothwell, 2014)

The female reproductive period runs when the female has been successfully fertilized by the male. The female pregnancy process for 3 weeks continued with a crawler income of 1.5 to 2 months. The outgoing crawler will search for a feeding location and stay for 1-3 days and turn into a white hat and stage of the nipple that will magnify his shield. Black hat occurs perfect one week after experiencing stage of white hat nipple.

Black hat will experience first molting directly and distinguish themselves between males and females so that the stage that is often found is the second instar of females and male second instar. Both male instars and male instars take two weeks to get to the next stage. The second instar of the female enters the second molting by releasing its shield for a moment while the male instars enter the preposition phase.

The male preliminary phase takes 5 days to enter the pupa phase. In this case there will be a bright shield color change becomes darker. After 3 days experience the pupa phase will be produced imago male complete with wings, antenna and reproduction tool, but the age of male imago only one week. 
For females, when entering the second molting takes one week to reach the third instar of the female. The third instar of the female is a mature female. This third instar enters virgin virginity where at this time the female is able to live waiting to be fertilized for up to 3 months.

Table 2 - The Process of Death D. Perniciosus

\begin{tabular}{|l|c|c|c|c|c|}
\hline The process of death & $\begin{array}{c}\text { Number of } \\
\text { detected scales }\end{array}$ & $\begin{array}{c}\text { The number of } \\
\text { dead scales }\end{array}$ & $\begin{array}{c}\text { Death } \\
\text { rate }(\mathrm{d})\end{array}$ & $\begin{array}{c}\text { Endurance } \\
\text { Level }(\mathrm{s})\end{array}$ & $\mathrm{K}$ value $[-\operatorname{In}(\mathrm{s})]$ \\
\hline Parasitoid & 224 & 32 & 0,14 & 0,86 & 0,15 \\
\hline Mushrooms & 192 & 8 & 0,04 & 0,96 & 0,04 \\
\hline Natural & 184 & 12 & 0,07 & 0,93 & 0,07 \\
\hline \multicolumn{1}{|c|}{ Total } & 230 & 52 & 0,23 & 0,77 & 0,26 \\
\hline
\end{tabular}

The table above shows that the process of scales death is caused by parasitoids, fungi and death naturally. Death by parasitoids is caused by Encarsia sp. whereas death is naturally caused by microclimate conditions such as rainfall. The highest mortality rate is caused by the parasitoid of 0.14 and for the highest scaling resistance level is in the mushroom of 0.96 . The precision value of the scales is 0.15 for the parasitoid and the total of all these controls is 0.26 . The highest accuracy result in this test is $100 \%$ with $k=1$.

Table 3 - Sex Ratio D. Perniciosus

\begin{tabular}{|l|l|l|l|l|}
\hline Stage Development & Number of Living & Death Factor & Number of dead & Percent of Death (\%) \\
\hline Crawler & 89 & Natural & 12 & 13 \\
\hline Nymph & 77 & Parasite & 40 & 52 \\
\hline Adult & 37 & \multicolumn{2}{|c|}{ (Sex Ratio 1:1,5, 12,33 male \& 24,67 female) } \\
\hline
\end{tabular}

Some of the decline caused by several factors, among others, natural and parasite. Natural can be interpreted as the death of scaly lice caused by environmental factors such as rainfall, humidity and temperature while parasit interpreted as the death of scales due to the influence of natural enemies in this case is parasitoid and entomopatogenic fungi. The total number of parasites is $52 \%$, which indicates that both agents are compatible so that the hope is that pest control will work optimally in the future by increasing the potential of the two natural enemies.

The development of stadia experienced in 3 major groups namely crawler, nymph and adult. And it is known that the sex ratio of male and female is 1: 1.5. This indicates dominance is found in females while the dominant subtropical region is present in males. If the environment supports sex dominance will be present in males and vice versa if conditions are less supportive then the sex dominance will be present in females. Given that apples are not native to Indonesia in the tropics.

For information, in the New Zealand region red marks caused by the crawler that turned into nymph. At harvest time, it was found that $62 \%$ produced a red mark effect and $41 \%$ did not. And after it was identified that the cause of the red mark was 173 males and 94 females with a 2: 1 sex ratio and that did not result in red marks were 198 males and 184 females with a sex ratio of $1: 1$. In this case it can be concluded that the resulting red marks are dominant in males (Crop Protection Compendium, 2014)

At an average temperature of $22.4^{\circ} \mathrm{C}$ in Tulungrejo Village, the crawler will experience a long life cycle of between 42-60 days (Table 4). This is supported by Luck (1995), that due to an increasingly long life cycle resulted in less number of generations of scales per year in areas with low temperatures.

Minimum temperature ranges from $19^{\circ} \mathrm{C}$ in Tulungrejo village so this will depress the number of crawler scavengers. The mortality rate of scales in natural conditions is $13 \%$ under these conditions (Table 3). Huba (1962) emphasized that when the temperature reached $14{ }^{\circ} \mathrm{C}$ then all crawlers began to die to $73 \%$.

The first, second and third instars are the ones that are most resistant to low temperatures while the females with crawlers are resistant to medium temperature. The first molting both male and female, molting both females, male prapupa and male pupae are very 
susceptible to low temperatures. Thus, low temperatures are the most decisive factor for scaling abundance and spread (Smith et al., 1997).

Table 4 - Lifecycle D. perniciosus at a certain temperature (CABI, 2009)

\begin{tabular}{|c|c|}
\hline Temperature & Perfect life cycle (days) \\
\hline $20-21^{\circ} \mathrm{C}$ & 60 \\
\hline $25-26^{\circ} \mathrm{C}$ & 42 \\
\hline $31-32^{\circ} \mathrm{C}$ & 30 \\
\hline
\end{tabular}

Air temperatures are predicted to determine behavioral trends. Hot temperatures are believed to be a driving factor in the emergence of aggressiveness. On the other hand a very cold temperature is estimated to reduce aggressiveness. This is evident in the shielding of the scalps within a period of just 1 day indicating that the scooter scales does not take long to choose and settle due to the heat-induced air in the maximum temperature seen in Figure 11 given that the shield function is also to protect the scales of the surrounding environment circumstances are less conducive.

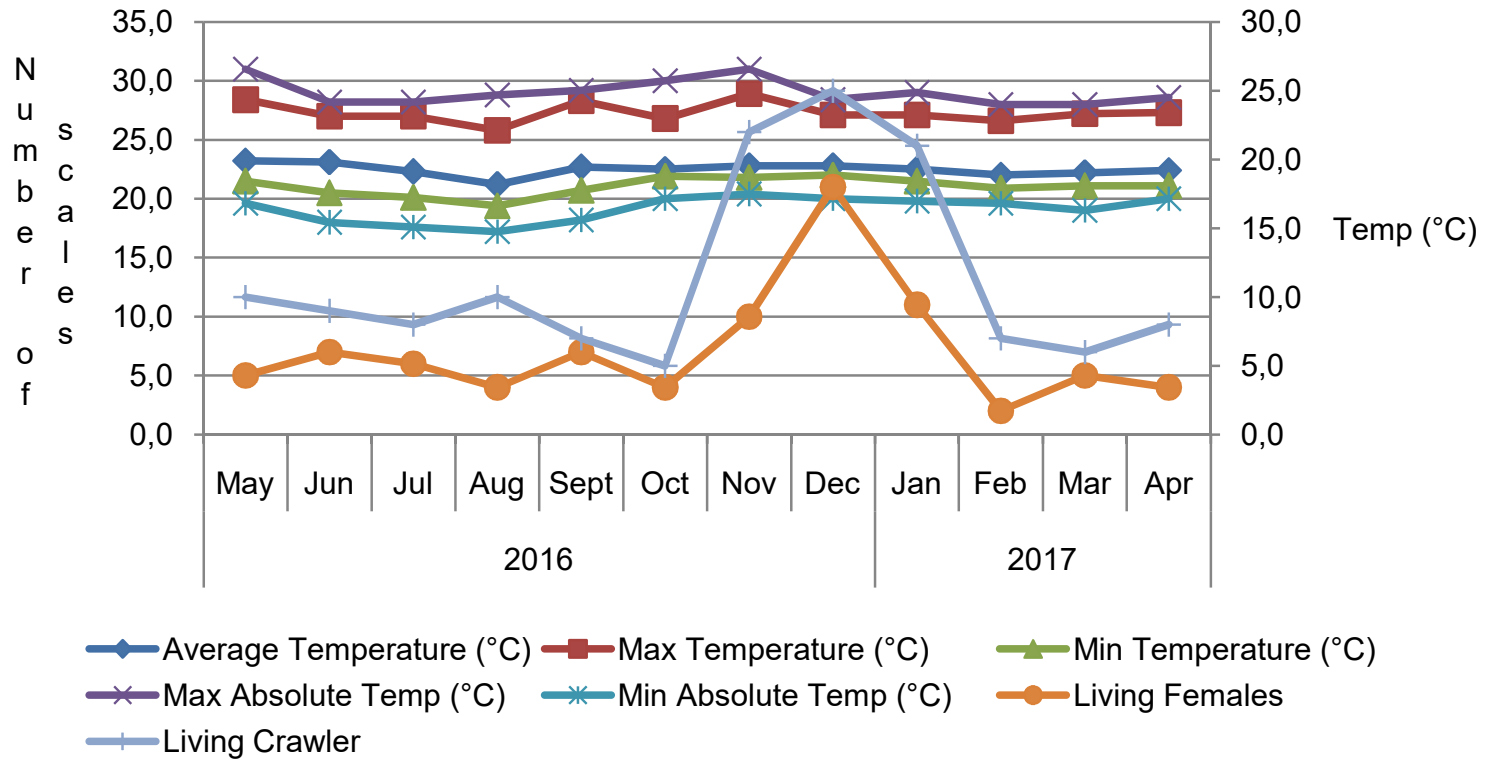

Figure 11 - Relation of temperature and the scale insect

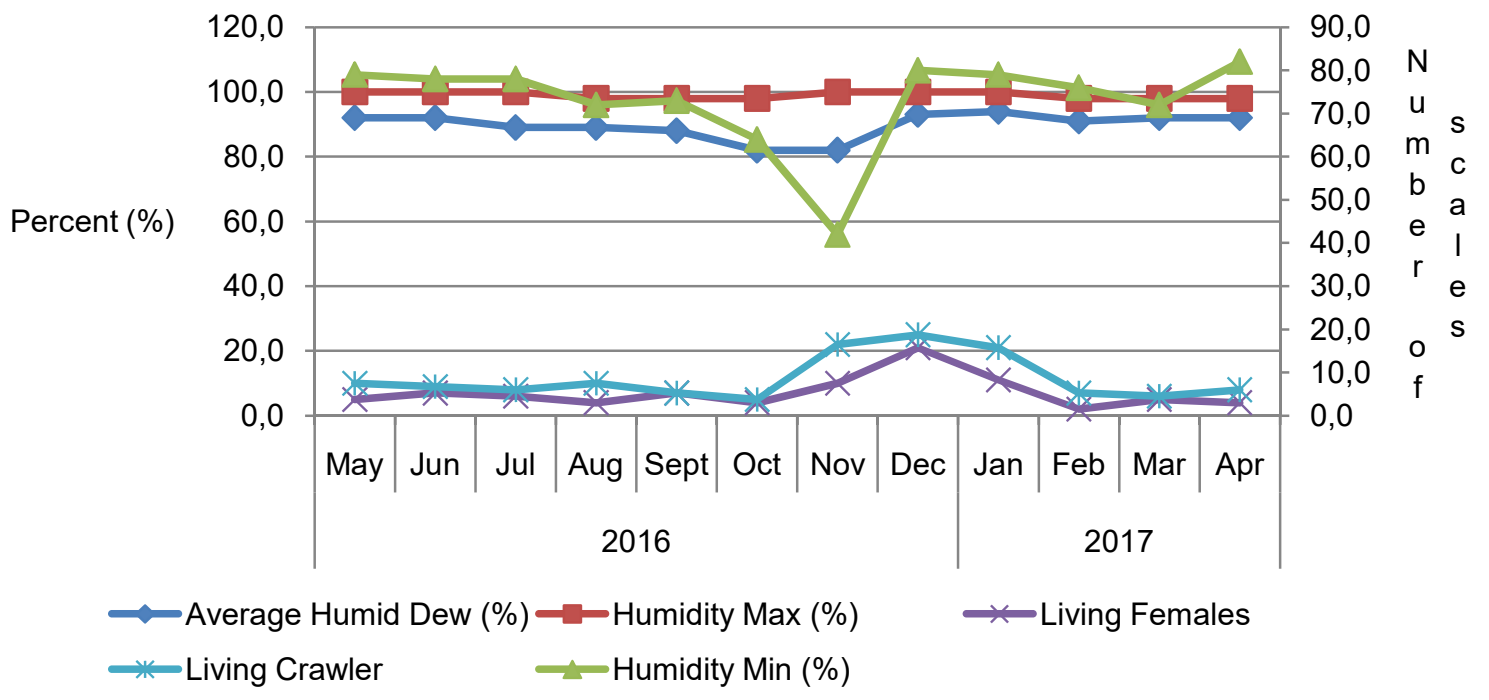

Figure 12 - Relation of humidity and the scales insect 
The required air humidity of apple plants is about $75-85 \%$ and the actual condition at observation is higher that is $89.8 \%$ (Figure 12). High humidity can stimulate the growth of microbes that can harm plants. But in certain aspects it can also support the entomopathogenic fungi that can help control the scale insect. In this study it was found that when the minimum relative humidity reaches $47 \%$, the scaling condition of the scales increases. Luck (1995) states that the generation of scales per year is lower in areas with high humidity. But to achieve the best way out, it prevents high moisture around the plant by pruning unproductive branches.

\section{CONCLUSION AND RECOMMENDATIONS}

The total population of scales that can occur in one year is 1322 individu with a generation of 7.20 months and the rate of breeding speed of 3.21 individu in one sibling. Decrease of scales occurs in March to May and September to November. In March to May it is suspected to be caused more by natural enemies, whereas in September to November it is caused more by rainfall factor.

Suggestion. The abundance of scales should be seen in depth both in relation to abiotic and biotic factors so that the results will be obtained more leverage.

\section{REFERENCES}

1. CABI Crop Protection Compendium. 2009. Quadraspidiotus perniciosus. Datasheet http://www.cabi.org/compendia/cpc/oorten\&id=108.

2. Crop Protection Compendium [databaseonline], Diaspidiotus perniciosus, 2014, online<http://www.cabi.org/cpc/datasheet/46224\#tab1-nav> [cit. 2014-08-11]. Diakses pada tanggal 23 November 2015 Pukul 10.00 WIB.

3. Fahriyah, Heru S., and Sherley S. 2011. Impacts of Climate Change on Production and Revenue of Apple Farmers (Malus sylvestris). Agrise XI, (3): 189-194.

4. Huba, A. 1962. The prognosis of the spread and harmfulness of the San Jose scale (Quadraspidiotus perniciosus Comst.) in Europe (In Czech). Polnohospodarstvo 9 (5-6), 415-421.

5. Indahwati, R. Budi H., and Munifatul I. 2012. Arthropod Diversity of Soil in Tulungrejo Village Tulungrejo Subdistrict, Batu Bumiaji Sub-District. Paper presented at the National Seminar on Natural Resources and Environment Management, Diponegoro University, Semarang, September 11, 2012.

6. Koteja, J. 1990. Life History. In Rosen, D. Armored Scale Insects: Their Biology, Natural Enemiesand Control, Vol 4A. Elseiver, Amsterdam, Oxford, New York, Tokyo. 243-254.

7. Luck, R.F. 1995. Biological Control in The Western United States. Division of Agricultrure and Natural Resources. University of California. Pp 155-157.

8. Miller D.R., and Davidson J.A. 2005. Armored Scale Insect Pests of Trees and Shrubs (Hemiptera: Diaspididae), Ithaca: Cornell University Press, XII. Pp 442. ISBN 0-80144279-6.

9. Rothwell, N. 2014. Time for San Jose Scale. Department of Entomology. Michigan State University Extension. Available online at: msue.anr.msu.edu Diakses 21 Maret 2016.

10. Scales Attack 9 Hectares Apple Garden. Radar Batu Jawa Pos Saturday 20 August 2015 pp. 37-38

11. Schauff M.E. and Gregory A.E. 2014. A Pictorial Guide to the species of Encarsia (Hymenoptera: Aphelinidae) parasitic on whiteflies (Homoptera: Aleyrodidae) in North America. (MES) Systematic Entomology Laboratory, PSI, USDA, c/o National Museum of Natural History, NHB 168, Washington, D.C. 20560. (GAE) Department of Nematology and Entomology, University of Florida, Gainesville, FL 32611.

12. Smith Jr J.W., R.N Wiedenmann and F.E Gilstrap. 1997. Challenges and Opportunities for Biological Control in Ephemeral Crop Habitats: an Overview. Biolo Contr 10: 2-3. 
13. Smith, I.M., McNamara, D.G., Scott, P.R. \& Holderness, M. 1997. Quarantine Pests for Europe, 2nd Edn., CABI / EPPO, Wallingford, 1425pp. Additional comprehensive information is also available at: http://nlbif.eti.uva.nl/bis/diaspididae.php?selected=beschrijving\&menuentry=s

14. Sunarjono, H. 2013. Gardening 26 Types of Fruit Plants. Jakarta. The Swadaya spreader. p. 156-160.

15. Triwiratno, A. 2008. Collection of New Varieties of Apples from the Netherlands State. Sinar Tani Magazine Edition: 17. Batu: Research Institute of Citrus and Subtropical Fruits.

16. Watson, G,W. 2002. Arthropods of economic importance: Diaspididade of the world. Series title: World biodiversity Database. Expert Center for Taxonomic Identification (ETI) Bioinformatics, Leiden, The Netherlands. 